\title{
ACCESS TO ECOLOGICAL JUSTICE FOR THE MARGINALIZED PEOPLE OF INDONESIA: IS IT A GENUINE OR PSEUDO RECOGNITION AND RESPECT?
}

\author{
I Nyoman Nurjaya* and Rachmad Safaat**
}

\author{
* Professor of Law, Faculty of Law, Brawijaya University, Malang, Indonesia \\ ** Faculty of Law, Brawijaya University, Malang, Indonesia
}

\section{Article Info}

Received : 23 February 2016 | Received in revised form : 14 April 2016 | Accepted : 26 April 2016 Corresponding author's e-mail : nurjayai@yahoo.com

\begin{abstract}
The era following the 1972 Stockholm Declaration and subsequently the 1992 Rio de Janeiro Declaration, brought about a great amount of concern of the international community, in developed as well as under-developed countries, for human environment and natural resources preservation, management and protection. It includes the equitable allocation and distribution of natural resources as well as fair participation in environmental decision-making, respect and recognition of rights of the people and particularly indigenous communities. This is the so called access to justice for all that refers to a genuine access by people and communities to obtain just and fair democratic mechanism in respect and recognition of their basic legal rights in controlling and utilizing natural environment and resources for survival. Furthermore, access to justice means strengthening the fair involvement of the people with respect to preserving and managing the natural environment for sustainable development as to fulfill human rights as reflected in the State's Constitution and legislation. In the context of Indonesia, the above mentioned rights of the people and communities to ecological justice are clearly articulated in the 1945 Constitution. The paper attempts to convey a critical analysis as to whether the 1945 Constitution provides a genuine or pseudo respect and recognition in relation to access to ecological justice of the people and particularly for marginalized people, namely indigenous people (masyarakat adat) in the multicultural state of Indonesia.
\end{abstract}

Keywords: access to ecological justice, marginalized people, multicultural state of Indonesia

\begin{abstract}
Abstrak
Dekade setelah Deklarasi Stockholm tahun 1972 dan kemudian dilanjutkan dengan Deklarasi Rio de Jenairo pada tahun 1992 dapat dikatakan sebagai titik awal perubahan cara pandang masyarakat internasional di negara-negara maju maupun sedang berkembang mengenai bagaimana seharusnya lingkungan hidup dan sumber daya alam dimanfaatkan dan dikelola dalam pembangunan yang berkelanjutan dan berkeadilan. Karena itu, sejak tahun 1980-an wacana akses untuk memperoleh lingkungan yang baik dan sehat dan keadilan dalam alokasi dan distribusi pemanfaatan sumber daya alam (keadilan ekologi)sebagai hak warga negara menjadi perbincangan serius terutama di negara-negara sedang berkembang termasuk Indonesia. Wacana serius yang dimaksud adalah bagaimana Negara memberi jaminan pengakuan dalam pemenuhan hak warga negara memperoleh lingkungan yang baik dan sehat dan keadilan dalam pemanfaatan sumber daya alam terutama bagi warga negara yang termarjinalisasi seperti persekutuanpersekutuan masyarakat hukum adat di daerah sebagaimana diatur dalam Undang-Undang Dasar Negara Republik Indonesia Tahun 1945. Artikel mencoba untuk mengkaji kritis dan memberi pemahaman apakah akses memperoleh keadilan lingkungan dan pemanfaatan, khususnya akses warga masyarakat hukum adat di Indonesia, seperti dalam Konstitusi Negara Tahun 1945 adalah pengaturan dan pengakuan yang hakiki (genuine) atau semu dan setengah hati (pseudo)?
\end{abstract}

Kata Kunci: akses keadilan ekologi, jaminan pengakuan dan pemenuhan hak, persekutuan masyarakat hukum adat 


\section{Introduction}

Access to justice in the broad sense refers to a condition and process whereby the State guarantees the fulfillment of citizens' basic legal rights granted by the State's Constitution and the 1948 Universal Declaration of Human Rights. Therefore, access to justice is defined as access to fair, effective and accountable mechanism for the recognition and protection of rights, control against abuse of power, and resolution of conflicts, including the ability of people to seek and obtain a remedy through the formal and informal justice system. The definition emphasizes that access to justice aims to support and strengthen the prevention and alleviation of poverty, as well as to protect and fulfill human rights through legal empowerment of the people.

In recent decades after the 1972 Stockholm Declaration ${ }^{1}$ there has been growing concern for natural environmental justice. ${ }^{2}$ Environmental justice is fair treatment and meaningful involvement of all people with respect to the development, implementation and enforcement of environmental laws and policies. It includes equitable distribution of environmental risks and benefits, fair and meaningful participation in environmental decision-making, recognition of the community's way of life, local knowledge and cultural differences, as well as the capabilities of the communities and individuals to function and flourish in society. ${ }^{3}$

Environmental justice emerged as a concept in the United States in the early 1980s. It was a response to environmental injustice, with the lack of 'fair treatment' to, in particular, people and social groups that are already marginalized and disadvantaged. The term of environmental justice has naturally two distinct uses. The first and more common usage describes a social movement the focus of which is the fair distribution of environmental and ecological benefits and burdens; and second, it is an interdisciplinary body of social science literature that includes theories of the environment, theories of justice, environmental law and governance, environmental

${ }^{1}$ The 1972 Stockholm Declaration launched with the purpose of encouraging participating countries as well as United Nations agencies to integrate environmental measures into their own environmental programs and activities which defined global principles for the preservation and enhancement of the human environment, as well as highlighted the need to encourage participating countries in designing environmental assessment, financial assistance, as well as environmental policy and legislation. Reaffirming the Declaration the so called UN-Conference on Environment and Development (UNCED) carried out at Rio de Janeiro from $3^{\text {rd }}$ to $14^{\text {th }}$ June 1992 for the purpose of establishing a new and equitable global partnership through the creation of new levels of collaboration among States with respect to the interests of all and protect the integrity of the global environmental and development system. The 1992 Rio Declaration defines that the only way to have long term economic progress is to link it with environmental protection. Recognizing the integral and interdependent nature of the Earth, our home, the nations meeting at the Earth Summit in Rio de Janeiro adopted a series of principles to guide future environmental management and development. These principles constitute the rights of people to development, and their responsibilities to safeguard the common environment. The said global principles build on ideas from the Stockholm Declaration. Accordingly, in relation to the development of environmental law and governance, Indonesia as member of the international community should accommodate those global principles defined in the mentioned Stockholm as well as the Rio de Janeiro Declarations. I Nyoman Nurjaya, "Progressive Environmental Law of Indonesia: Global Principles of Stockholm and Rio Declations As Defined In The 2009 Act on Human Environment Protection and Management," The US-China Law Review Vol.11 No. 1 (January 2014).

${ }^{2}$ Stefanie Glotzbach, "On the Notion of Ecological Justice," (Working Paper Series in Economics University of Luneburg, Germany, 2011).

${ }^{3}$ David Schlosberg, "Three Dimensions of Environmental and Ecological Justice," (Paper presented at Workshop the Nation-state and Ecological Crisis: Sovereignty, European Consortium for Political Research Annual Joint Sessions, 2001). 
policy and planning development, sustainable and political ecology. ${ }^{4}$

Indonesia has been well known in the world as a rich country in terms of its natural resources and biological diversity. Nevertheless, since the last four decades or more Indonesia has witnessed its natural resources stock and commodities decreasing and degrading both in terms of quality and quantity in line with the rapid implementation of economic development in the country. Accordingly, natural resources consisting mainly of forests, gas and oil, mineral mining, and fishery resources have been explored and exploited widely in the name of national development and for the sole purpose to enhance State revenues.

In recent years Indonesia has made significant progress toward greater democracy and protection of human rights. However, there remain several instances of unjust treatment of disadvantaged and marginalized people, namely indigenous ${ }^{5}$ people in the regions. In the last four decades or more Indonesia has been increasingly facing conflicts over natural resources access, use and tenure parallel to the rapid implementation of national development. ${ }^{6}$ Consequently, national development which is mainly directed and targeted to secure increasing economic growth and particularly the generation of State revenues has had to pay a high price in the form of serious economic losses and ecological degradation, as well as social and cultural destruction in the life of indigenous people in the various regions of Indonesia. ${ }^{7}$

The ecological degradation, economic losses, and social-cultural destruction mentioned above have occurred primarily due to differences in perception and interest of natural resources control and utilization between the Government and the local indigenous people. In this sense, the Government tends to enforce State law, namely legislation and regulations, to control resources in the name of national development while the indigenous communities employ their customary law to access and utilize the natural environment in the territories they depend on for survival. Hence, conflicts over natural resources tenure and utilization between the Government and the indigenous people could not be deflected in the country. ${ }^{8}$ Such legal phenomenon clearly reflects a condition of unjust treatment of the indigenous people as citizens particularly over access to and utilization of the natural environment in the territory they depend on for survival.

The paper attempts to raise critical questions and critique whether access to ecological justice for the indigenous people of Indonesia as clearly defined in the 1945 Constitution and natural resources laws is a genuine or pseudo recognition and respect?

\footnotetext{
${ }^{4}$ Ilaria Beretta, "Some Highlights on the Concept of Environmental Justice and Its Use," https://eces. revues.org/1135; Marina de Oliveira Finger and Felipe Bortoncello Zorzi, "Environmental Justice," UFRGS Model United Nations Journal Vol. 1 (2013): 222-243.

${ }^{5}$ In the context of Indonesia, the term "indigenous people" is referred to masyarakat adat.

${ }^{6}$ Sukri Abdurrachman, Konflik Pertanahan di Era Reformasi: Hukum Negara, Hukum Adat dan Tuntutan Rakyat [Conflict of Land Tenure in Reformation Era: State Law, Adat Law and Claims by the People], (Jakarta: Pusat Penelitian Kemasyarakatan dan Kebudayaan LIPI, 2004).

${ }^{7}$ I Nyoman Nurjaya (1), Pengelolaan Sumber Daya Alam dalam Perspektif Antropologi Hukum [Natural Resources Management in the Perspective of Legal Anthropology], (Jakarta: Pustaka Prestasi Publisher, 2008); John Bodley, Victims of Progress, (California: Mayfield Publishing Company, 1982); Robert Repetto \& Malcolm Gillis, Public Policies and the Misuse of Forest Resources, (New York: Cambridge University Press, 1988).

${ }^{8}$ Anthony Allot and R. Woodman Gordon, (Eds), People's Law and State Law, (Dodrecht-Holland: Foris Publication, 1975).
} 


\section{Environmentally Sound Principles of the 1972 Stockholm and the 1992 Rio Declarations}

The essence of the human environment and natural resources has been actually the essence of human life. It refers to the air, water, land, forest, river, lake, coast, sea, oil and gas, mining and mineral, biological diversity and everything within the earth and natural resources contained therein. Therefore, human environment is defined as a unity of the spatial entity with all objects, potentials, conditions and living organisms, including man and his behavior, which influence the continuance of the life and welfare of human beings and other living organisms. The human environment is naturally a system of life comprising the organic natural environment, inorganic natural environment, social environment, and the man-made environment, which influence the continuity of life and the welfare of human beings and other living organisms.

In 1972 the United Nations hosted a Conference on the Human Environment in Stockholm to provide a forum to discuss international co-operation in the area of environment preservation and protection, as well as to find solution to problems related to the environment. Environmental management principles embodied in the 1972 Stockholm Declaration make clear that numerous ecological crises threatening the planet at the time demanded worldwide attention and effort. ${ }^{9}$

Some of the well-known principles among the twenty-six principles defined in the 1972 Stockholm Declaration are as follows: (a) living environment is a basic human right. Therefore. the duty of protecting and preserving the environment is a responsibility for all (Principle 1); (b) natural resources and ecosystem must be safeguarded (Principle 2); (c) recognizes a special responsibility to safeguard and wisely manage the imperiled heritage of wildlife and its habitat (Principle 4); (d) serious or irreversible damage that exceeds the capacity of the environment must be halted (Principle 6); (e) taking steps to prevent pollution is a responsibility of States (Principle 7); (f) not to cause damage to the environment of other States or areas beyond the limits of national jurisdiction is a responsibility of States (Principle 21): (g) co-operation of developing international law regarding liability and compensation is a responsibility of States (Principle 22); (h) multilateral or bilateral cooperation to effectively control, prevent, reduce, and eliminate adverse environmental effects is necessary (Principle 24); and (i) to implement coordinated, efficient, and dynamic functions for the protection and improvement of the environment is a role of international organizations (Principle 25).

The 1992 Earth Summit in Rio de Janeiro defines a set of principles to guide future development in which the rights of people to the environment and development are recognized, and their responsibilities to safeguard the common environment formulated as to build on ideas from the 1972 Stockholm Declaration. The emphasis of the 1992 Declaration of Rio was on the protection of the environment and the advancement of development, giving priority to both, and calling for social and economic development processes to take the environment into account, that the only way to have long term economic progress is to link it with environmental protection. ${ }^{10}$ This will only happen if nations establish a new and equitable global partnership involving governments, their people and key sectors of societies in order

\footnotetext{
${ }^{9}$ Marie-Claire Cordonier Segger and Ashfaq Khalfan, Sustainable Development Law, Principles, Practices and Prospects, (Oxford: Oxford University Press, 2004), p. 17.

${ }^{10}$ Ibid., p. 20.
} 
to establish international agreements that protect the integrity of the environment and developmental policy.

Some of the urgent principles among the twenty-seven principles enshrined in the 1992 Rio Declaration are as follows: (a) human beings are at the center of concerns for sustainable development. People are entitled to a healthy and productive life in harmony with nature (Principle 1); (b) the right to development must be fulfilled so as to equitably meet development and environmental needs of present and future generations (Principle 3); (c) in order to achieve sustainable development, environmental protection shall constitute an integral part of the development process (Principle 4); (d) States shall enact effective environment legislation (Principle 11); (e) States shall develop national law concerning liability and compensation for the victims of pollution and other environment damage (Principle 13); (f) States shall employ the precautionary approach to protect the environment (Principle 15); (g) States shall provide prior and timely notification and relevant information to potentially affected States on activities that may have a significant adverse transboundary environmental affect and should consult with those States at an early stage in good faith (Principle 19); (h) indigenous people and their communities and other local communities have a vital role in environmental management and development due to their knowledge and traditional practices. States should recognize and duly support their identity, culture and interests and enable their effective participation in the achievement of sustainable development (Principle 22).

Indonesia as member of the international community has a moral obligation to protect and conserve its natural resources and living environment in order to maintain sustainable national development, as well as to contribute to the global community's endeavors in maintaining climate stability and sustainable environment and resources management internationally under the supervision of environment and resources management principles of living environmental justice, democratic and sustainability as provided for in the 1945 Constitution and the State's environmental law and policy.

\section{III.Ideology of the State in Protecting the Rights of Indigenous Communi- ties Over Human Environment and Resources: A Genuine or Pseudo Recognition and Respect?}

Law is a definitional characteristic of the State and an object of efforts of the State to govern and control its territory and natural resources contained therein. It is therefore crucial to pay attention to the role of law as ideology, and to analyze how the State establishes and enforces the ideology. ${ }^{11}$ In the case of Indonesia, it is clearly observed that law has been enacted and employed as ideology in order to govern and control the territory and natural environment contained therein as clearly defined in the Preamble of the 1945 Constitution as follows:

...... forming a Government which shall protect the entire people and control the territory and natural resources contained therein mainly for the purpose of enhancing

${ }^{11}$ Charles V. Barber, "The State, The Environment, and Development: The Genesis and Transformation of Social Forestry Policy in New Order Indonesia," (Unpublished Doctoral Dissertation University of California, Berkeley, 1989); David Schlosber, "Three Dimensions of Environmental and Ecological Justice," (Paper presented at Workshop the Nation-state and Ecological Crisis: Sovereignty, European Consortium for Political Research Annual Joint Sessions, 2001). 
prosperity and the people's welfare, educate and produce smart people, and to participate in the establishment of world order based on freedom, perpetual peace, and social justice. [Unofficial translation].

The said Preamble naturally reflects the main objective of the establishment of the State of the Republic of Indonesia, as well as a kind of ideology that should be used as foundation in order to unite the nation and build the character of the country. Accordingly, such ideology is reaffirmed particularly in Article 33 Paragraph (3) of the 1945 Constitution which that states as follows:

The land and water and natural resources contained therein should be controlled by the State and shall be utilized for the greatest prosperity of the people. [Unofficial translation]

Key words of the ideology of the State in controlling and managing natural resources can be found in the following two phrases: "...should be controlled by the State" and "shall be utilized for the greatest prosperity of the people".

In addition to the above, another provision which indicates that the 1945 Constitution is an 'environmentally sound and friendly Constitution' is formulated in Article 28H Paragraph (1) which sets out as follows:

Every person shall have the right to live in physical and spiritual prosperity, to have a home and to enjoy a good and healthy environment, and shall have the right to obtain medical care. [Unofficial translation]

Reaffirmation of the said Article is stated in Article 65 of Law No. 32 Year 2009 regarding Human Environment Protection and Management stating as follows:

Everybody shall be entitled to a proper and healthy environment as part of human rights, and shall be entitled to environmental education, access of information, access of participation and access of justice in the fulfillment of the right to a proper and healthy environment. ${ }^{12}$ [Unofficial translation]

In relation to the recognition and respect of the indigenous people referred to as masyarakat adat spread throughout the regions, Article 18B Paragraph (2) of the 1945 Constitution states as follows:

The State recognizes and respects indigenous communities and their traditional rights as long as these remain in existence, and are in accordance with the societal development, and the principles of the Republic of Indonesia, and shall be regulated by a Law. [Unofficial translation]

In this sense, key word of the Article which requires serious attention is "... as long as...." It clearly indicates that the 1945 Constitution defines an officially accepted restriction that the existence of indigenous people in the country will only be recognized and respected by the State as long as they fulfill abstract and certain conditions namely (a) they still actually exist in real life, (b) living as and in accordance with civilized societal progress, and (c) are not in contradiction with the principle of the unitary State, and (d) are to be regulated by State law. On the other hand, Article 6 Law No. 39 Year 1999 regarding Human Rights clearly defines that (1) in the interest

${ }^{12}$ Therefore, according to Law No. 32 Year 2009, environmental protection and management shall aim at: (a) protecting the territory of the Unitary State of the Republic of Indonesia from environmental pollution and/or damage; (b) guaranteeing human safety, health and life; (c) guaranteeing the continuation of life of creatures and ecosystem conservation; (d) preserving the functions of the environment; (e) achieving environmental harmony, synchronize and equilibrium; (f) guaranteeing the fulfillment of justice for the present and future generations; ( $\mathrm{g}$ ) guaranteeing the fulfillment and protection of right to the environment as part of human right; (h) controlling the utilization of natural resources wisely; (i) realizing sustainable development; and (j) anticipating global environmental issues.[Unofficial translation.] 
of upholding human rights, the differences and needs of indigenous people must be taken into consideration and protected by the law, the public and the Government; (2) the cultural identity of indigenous people, including indigenous land rights, must be upheld, in accordance with the progress of life in society.

The above described conditions have been further reaffirmed in the State's legal instruments which provide for the control and management of natural resources in the territory of adat communities. The said legal instruments are as follows: Law No. 5 Year 1960 regarding Basic Regulations of Agrarian Principles which deals with land tenure and use; Law No. 41 Year 1999 regarding Forestry pertaining to forest resources control and management; Law No. 5 Year 1990 regarding Biological Diversity Conservation; Law No. 24 Year 1992 regarding Spatial Use; Law No. 7 Year 2004 regarding Water Resources; Law No. 18 Year 2004 regarding Plantation; Law No. 31 Year 2004 regarding Fishery; Law No. 27 Year 2007 regarding Coastal Zone and Small Islands Management; Law No. 4 Year 2009 regarding Mineral Mining and Coal; and Law No. 32 Year 2009 regarding Human Environment Protection and Management. The condition of "as long as" stated in the aforementioned Laws has certain consequences which result in clear restriction and neglect of the rights of indigenous communities to control, access, and utilize natural resources they depend on for surviving in their respective territories. Apart from that, the customary law of adat communities that reflect traditional environmental and ecological wisdom also became automatically dominated and subordinated and ignored by the State's Law concerning the tenure, management and utilization of natural resources. ${ }^{13}$

Prior to the proclamation of Indonesia's independence on August 17, 1945, indigenous communities had existed for years and generations, living in peace in certain territories mostly in and around forest areas or coastal zones as well as small islands. They have controlled and managed their natural environment they depend on under the supervision of their own indigenous law (adat law). This indicates that the ideology and character of State law in which conditions of as long as are attached as legal instrument to restrict the rights of indigenous communities is in contradiction with the principle of ad prima facie, namely which one is prior and posterior in existence in the territory of Indonesia, whether the traditional adat communities or the Nation State of Indonesia? It is generally recognized that indigenous people and communities in the country are naturally the basic elements of the establishment of State of the Republic of Indonesia.

From the vantage of legal anthropology, such ideology brings about the consequence that State law tends to dominate, marginalize, and even ignore the indigenous law of the local communities which remains naturally in existence as living law in the country as contended by Eugen Ehrlich. Even though indigenous law is declared as the only basic principle of Law No. 5 Year 1960 regarding Basic Regulations of Agrarian Principles, the capacity of indigenous law in such position and legal standing needs further clarification in the context of Indonesia's legal system. In this respect, as pointed out by Hart. The position of indigenous law in the law of the State could be referred to as the rule of recognition. ${ }^{14}$ The fundamental question that arises is whether it is a genuine or pseudo recognition and respect.

${ }^{13}$ I Nyoman Nurjaya (2), "State Law in Multicultural Country of Indonesia: Toward A Just and Equitable State in Legal Anthropology Point of View", in The US-China Law Review Volume 9, Number 1, February 2012, Illinois-USA: David Publishing Company.

${ }^{14}$ H.L.A. Hart. The Concept of Law, Oxford: Oxford University Press, 1960. 
The recognition of indigenous law within the law of the State is pseudo recognition in nature as intended by Hart. It is due to the attached restricting condition of "as long $a s^{\prime \prime}$ in the 1945 Constitution and a number of Laws pertaining to environment and natural resources control and access, which brings about the consequence that the legal standing and capacity of customary law of adat communities had been decreased at the level of both State ideology as well as legislation. In other words, this has resulted in the so called pseudo-Constitutional and Legal recognition and protection of the indigenous community rights for a clean, safe and healthy environment as well as natural resources they depend on to survive. ${ }^{15}$

What may be subject to critique in the above mentioned legislation in relation to the State's ideology are the legal position and capacity as well as the legal recognition of traditional indigenous communities within the dynamics of the life of the State of the Republic of Indonesia. On the one hand, indigenous communities and their indigenous laws are officially recognized and respected by the 1945 Constitution and legislation; while on the other hand, the existence of adat communities has been restricted with the condition of "as long as" in the sense of recognition and protection within the 1945 Constitution and legislation. It means that even though it is clearly stated that the environment and natural resources Law regarding land, water and air space, including natural resources contained therein, is basically indigenous law, the wording of "as long as" has diminished its legal position and capacity as the only foundation of the State's ideology and legislation.

In other words, the attached condition of "as long as" proves that indigenous law is actually subordinated by the State's natural resources law at the level of ideology and legislation. What then could be concluded from this brief description of the fact of legal plurality in the multicultural country of Indonesia? The answer seems to be clear, namely that the fundamental principle which is that indigenous law should form the basis of State's law, has been heavily qualified due to the wording "as long as" attached in the 1945 Constitution and legislation. The critique that it necessitates is whether in fact it can be allowed to continue. There is certainly little room for the view that the legislature has supported or underwritten adat as the primary source of the natural resources law, except to the extent that it does not conflict with the limits imposed upon it. ${ }^{16}$ In line with the political view of national law development formulated by the Government, this could be considered as the so called political ignorance of the State in terms of the existence of adat people and communities, as well as of their rights over environment and natural resources tenure and utilization, in addition to ignoring the living indigenous law as legal entity in the overall system of Indonesia's national law.

At the level of implementation and enforcement, factual conditions indicate that in a great number of cases indigenous law tends to be neglected and ignored by State law at times of tension and conflict between the Government and local adat communities over natural resources access and tenure in the country. It becomes apparent that the Government tends to neglect and disregard the rights of adat communities in terms of access, tenure, and utilization of resources in the territory they depend on for survival. Apart from that, in the context of empirical and political situation and conditions it can be observed that communities have been powerless in facing the Government at a

${ }^{15}$ I Nyoman Nurjaya (3), "Adat Community Land Rights As Defined In the State Agrarian Law of Indonesia: Is It A Genuine or Pseudo Legal Recognition?", in The US-China Law Review Volume 8, Number 4, April 2011, Illinois-USA: David Publishing Company; Nurjaya (4), loc.cit.

${ }^{16}$ H.B Hooker, Adat Law in Modern Indonesia, (Oxford: Oxford University Press, 1978). 
time when their right over territory and natural resources they depend on for survival are neglected and ignored and demised in the name of national development. ${ }^{17}$

In this respect, John Bodley states that the people whose traditional rights over natural resources and cultures are neglected and ignored in the name of progress and development are "victims of development". In his words Bodley states that Government policies and attitudes are the basic causal factors determining the fate of tribal cultures, and that governments throughout the world are concerned primarily with the increasingly efficient exploitation of the human and natural resources of the areas under their control. It is becoming increasingly apparent that civilization's "progress" destroys the natural environment as well as the indigenous people and cultures. $^{18}$

\section{State Law and The Folk Law: Legal Anthropology Point of View}

Global principles of ecological justice refer to the philosophy of fairness in natural resources management and policy, the fair treatment and meaningful involvement of all people with respect to the development, implementation, and enforcement of environmental laws and policies. It includes equitable distribution of ecological risks and benefits, fair and meaningful participation in ecological decision-making, recognition of community ways of life, local knowledge and cultural difference, and the capabilities of communities and individuals to function and flourish in society. The said policy should be planned, implemented, monitored, and evaluated with the purpose of protecting and preserving environmental and natural sustainability. It means that State law and policy in managing and utilising resources should be fair in terms of allocation and distribution inter-generations and particularly for the coming generations.

The democratic principle refers to the dimension of balancing legal standing between people and the Government in Nation State governance. It means that in the sense of relationship pattern between the two main actors, namely the people and the Government, there is no relationship pattern of super-ordinance and subordinance between the above mentioned two actors and neither is there a superior and inferior relationship pattern - both of them are equal and balanced in position before the Constitution and State law. Therefore, the principles of genuine public participation and transparency become essential principles in policy and decision making processes. The people should be regularly involved in the law making processes by the Government at the national and regional level based on the structure of the Government system concerned. Space for public participation should be opened up and provided within State law in the implementation of integrated national development particularly in natural resources management and utilization at the community level for the purpose of enhancing prosperity to the entire people of Indonesia.

The global principle of respect and recognition of communal rights of indigenous people over natural resources is an essential principle which should be taken into account in controlling and managing natural resources. It is the legal obligation of the State to respect and recognize the rights of indigenous people and local communities

\footnotetext{
${ }^{17}$ Michael R. Dove, Peranan Kebudayaan Tradisional Indonesia dalam Modernisasi [The Role of Traditional Culture in Modern Indonesia], (Jakarta: Yayasan Obor Indonesia, 1981).

${ }^{18}$ John Bodley, Victims of Progress, (California: Mayfield Publishing Company, 1982).
} 
that play a vital role in ecological and environmental management and development due to their knowledge and traditional practices. Therefore, States should also recognize, respect and protect their identity, culture and interests and enable their effective participation in the achievement of sustainable development

In summary, observing the establishment of national law, it could be stated that State law has become the idiom for expression of power to control its territory and manage natural resources contained therein. The establishment has systematically ignored and neglected the legal position and capacity of adat law as a naturally existing and living law of the people in the country. ${ }^{19}$ It brings about the consequence that natural resources control and management at the level of implementation and enforcement are mostly dominated by conflicts between the Government and the local communities particularly over natural resources access and tenure. In this sense, such conflicts are reflected in tensions on a larger scale between the central and regional Government and the local people in the regions.

In order to obtain a better understanding of the social and cultural context of law, we need to focus attention on the relationship between law and culture. In this respect, law is actually part of culture, and therefore law should be studied as an integral part of culture as a whole, rather than being regarded as an autonomous institution. ${ }^{20}$ Consequently, when we are speaking about the establishment of State law, other aspects of culture such as economy, politics, social aspects and culture as well as ideology should also be taken into account. In fact, these aspects of culture strongly influence the development of State law. That is why, in a number of obstacles faced for ideological, economic and political reasons can be observed in the context of the establishment of national law both at the level of law making as well as law implementation and enforcement.

Law cannot be understood without regard for the realities of social life. Therefore, if we wish to clarify the position and the capacity of adat law in the overall social and cultural structure of Indonesia, including law in particular, I encourage the employment of the concept of semi-autonomous social field as introduced by Moore. ${ }^{21}$ In this regard, society is described as a social arena in which a number of social fields have rule-making capacities, generate rules, customs and symbols internally, and the means to induce or coerce compliance that is referred to as so called self-regulation or legal order. However, they are simultaneously set in a large social matrix which can, and does, affect and invade its autonomy and means of legislation. Therefore, these social fields may be referred to as semi-autonomous social fields within the total structure of society.

It is a fact that Indonesia is a multicultural country in terms of ethnicity, religion, language, and social stratification, including the existence of multi-system of law namely State law on the one hand and religious law, customary law or adat law on the other hand. Such legal systems are functioning and are being put into effect simultaneously toward all members of communities, especially indigenous adat communities in the territory of the State of the Republic of Indonesia. Even so, it could be clearly observed that since the last four decades the Government has tended

\footnotetext{
${ }^{19}$ June Starr and Jane F. Collier, History and Power in the Study of Law, New Direction in Legal Anthropology, (Ithaca and London: Cornel University Press, 1989).

${ }^{20}$ Leopold Pospisil, Anthropology of Law, A Comparative Theory, (New York: Harper \& Row Publisher, 1971).

${ }^{21}$ Sally F. Moore, Law as Progress, An Anthropological Approach, (London: Routhledge \& Kegan Paul Ltd., 1978).
} 
to enforce the ideology of legal centralism in enhancing national environmental law development. Consequently, a number of environmental law products indicate a shift toward unification and codification of law shaped and enacted by the Government. This is the so called rule-centered paradigm which brings about the consequence of ignoring and marginalizing as well as dominating the other system of living law, namely traditional adat law which, in empirical legal fact, is implemented and functions much more effectively in the daily life of indigenous adat people and communities in the region. $^{22}$

In this regard, in the context of such law making politics, law making has been implemented by being intentionally directed and used in the function of an instrument of governmental social control, the servant of repressive power, ${ }^{23}$ as well as the command of a sovereign backed by sanction ${ }^{24}$. It is a repressive instrumentalism in which law is bent to the will of governing power. Hence, from the legal anthropology point of view, it could be stated that the source of the phenomena of legal conflicts, particularly conflicts over natural resources control and utilization between the government and the indigenous adat people that has been increasingly occurring in the last four decades in the regions, could be initially based on the employment of the legal centralism paradigm in the establishment of national environmental law. On the other hand, the empirical legal fact refers to the pluralistic social and cultural phenomena in which adat communities have the capacity to create and develop their own customary law in governing the natural environment they depend on for survival in the region concerned.

What needs to be done for creating an ambience of legal pluralism is to reformulate legal policy in the area of national environmental law making process within which the multicultural fact should be absolutely taken into consideration as a source of legal action in recognizing and protecting the real existence of living law within the life of adat communities in the country. This brings about the consequence that in the law-making process of environmental law, those values and principles of customary adat law must be accommodated and responded to as well as integrated into the system of national environmental law in the form of laws and legislation. It is, therefore, characteristic of natural environmental law that, reformed by the Government, it expresses the ecological and cultural diversity of Indonesia. In line with the recognition of such kind of law, it becomes what we refer to as responsive law, namely State law that is more responsive to the ecological and cultural diversity and social needs of the country. That is why the paradigmatic function of State law as instrument of social order and control, as well as a tool of social engineering could also be directed at strengthening the social integration of the Nation State leading towards a just and equitable environmental law for the entire people of Indonesia.

All of the foregoing indicates that the basis of law is naturally laid down in society itself. Hence, if we wish to obtain a better and more comprehensive understanding of law within society, law should be studied as part of culture integrally with other aspects of culture such a politics, economy, social structure, clan system, system of religion and the like. In this sense, we need to take a look at society and culture at

\footnotetext{
${ }^{22}$ Nurjaya (2), loc.cit.

${ }^{23}$ Philippe Nonet and Philip Selznick, Law and Society in Transition, Toward Responsive Law, (New York: Harper Colophon Books, 1978).

${ }^{24}$ Hilaire McCoubrey and Nigel D. White, Textbook on Jurisprudence, (London: Blackstone Press Limited, 1996).
} 
large in order to determine the place of law within the total structure. In other words, law as a system particularly in actual operation is basically a complex organism within which structure, substance, and legal culture interact with each other. Legal culture refers to those elements of general culture such as customs, opinions, ways of doing and thinking that bend social forces toward the law in particular, and therefore law expresses and defines the norms of the community concerned.

\section{Conclusion and Recommendations}

Fundamental environmentally-sound principles have been expressly articulated in Paragraph IV of the Preamble to the 1945 Constitution of the State of the Republic of Indonesia, which particularly sets out that the ultimate goal of the founding of the State of the Republic of Indonesia is to provide protection to all citizens of Indonesia and to preserve the territory and natural resources contained therein, to enhance genuine public prosperity for all citizens of Indonesia, as well as to develop smart and educated people, and take part actively in creating peaceful co-existence among nations throughout the world based on liberty, eternal peace, and social justice. Accordingly, in order to realize the primary purpose of Indonesia, focusing on the above mentioned basic environmentally-sound principles, it needs to be reaffirmed that the Indonesian living environment and natural resources control and management should be implemented in a wise manner.

With regards to the recognition and respect of indigenous people and communities, it is fair to conclude that the ideology of Indonesia, referring to Article 18B Paragraph (2) of the 1945 Constitution which defines a firm restriction that indigenous people are only to be recognized and respected by the State "as long as" they fulfill abstract and specific conditions, namely as long as they are still in existence, living as and in the civilized societal progress, as well as they are not in contradiction with the principles of the unitary State, and they are to be regulated by State law. This is the ideology of pseudo recognition and respect of the natural existence of indigenous adat people and communities in the multicultural country of Indonesia, particularly in relation to their fundamental rights in controlling and utilizing the natural environment and resources they depend on for survival.

The legal consequence of employing the ideology of pseudo recognition and respect of access to ecological justice of the marginalized indigenous adat people and communities is that such State ideology and legislation create inconsistency at the level of the Constitution, and injustice at the level of State law. The said theoretical framework outlined in the previous section is clearly significant in obtaining a better understanding with regard to such legal issue namely access to justice for marginalized people in the overall system of Indonesia's law, particularly in understanding the ideology of the State and the position and capacity of customary law as naturally living law of the indigenous adat people and communities in the country.

With respect to national law and policy development concerning natural environment and resources control and management, global environmentallysound principles should be adopted as natural environment and resources should be understood as a system of human beings' livelihood and as an ecological system; the natural environment and resources should mainly be managed and utilized for the purpose of enhancing the greatest prosperity of the entire people and communities; indigenous adat people and communities should be naturally involved in controlling 
and managing natural resources they depend on by using their environmental wisdom for years and generations that are reflected in customary law; indigenous people and communities have been the immediate actors and the best partners of the Government in the endeavors of managing the natural environment and resources in the country; customary law of indigenous communities should be naturally recognized and respected as part of the national law system; community-based natural environment and resources management should be conducted based on fundamental principles within the relationship pattern between indigenous adat people and the Government; and recognizing the environmental wisdom of the indigenous people and respecting the fundamental rights of communities and their customary adat law as a legal entity should be taken into account in the establishment of natural environment and resources legislation.

\section{Bibliography}

\section{Books}

Abdurrachman, Sukri. Konflik Pertanahan di Era Reformasi: Hukum Negara, Hukum Adat dan TunVutan Rakyat [Conflict of Land Tenure in Reformation Era: State Law, Adat Law and Claims of the People]. Jakarta: Pusat Penelitian Kemasyarakatan dan Kebudayaan LIPI, 2004.

Allot, Anthony and R. Woodman Gordon. Eds. People's Law and State Law. DodrechtHolland: Foris Publication, 1975.

Araf, Al and Awan Puryadi. Perebutan Kuasa Tanah [The Contest of Land Tenure and Control]. Yogyakarta: Lappera Pustaka Utama, 2002.

Bachriadi, Dianto. et. al. Eds. Reformasi Agraria, Perubahan Politik, Sengketa, dan Agenda Pembaruan Agraria di Indonesia [Agrarian Reformation, Political Change, Conflicts and Agrarian Reform Agendas in Indonesia]. Jakarta: Konsorsium Pembaruan Agraria (KPA) and Lembaga Penerbitan Fakultas Ekonomi Universitas Indonesia, 1997.

Bachriadi, Dianto. Sengketa Agraria dan Perlunya Menegakkan Lembaga Peradilan yang Independen [Agrarian Disputes and the Need for Enforcing An Independent Agrarian Court]. Bandung: Konsorsium Pembaruan Agraria (KPA), 1998.

Benedanto, Pax. Menggugat Ekspansi Industri Pertambangan di Indonesia [Claims Against Mining Industrial Expansion in Indonesia]. Bogor: Pustaka Latin, 1999.

Bodley, John. Victims of Progress. California: Mayfield Publishing Company, 1982.

Dove, Michael R. Peranan Kebudayaan Tradisional Indonesia dalam Modernisasi [The Role of Traditional Culture in Modern Indonesia]. Jakarta: Yayasan Obor Indonesia, 1981.

Harman, Benny K. Pluralisme Hukum Pertanahan dan Kumpulan Kasus Tanah [Pluralism in Indonesian Land Law and Compilation of Land Tenure Cases]. Jakarta: Yayasan Lembaga Bantuan Hukum (YLBHI), 1995.

Hart, H.L.A. The Concept of Law. Oxford: Oxford University Press, 1960.

Hooker, H.B. Adat Law in Modern Indonesia. Oxford: Oxford University Press, 1978.

Moore, Sally F. Law as Progress, An Anthropological Approach. London: Routhledge \& Kegan Paul Ltd, 1978.

McCoubrey, Hilaire and Nigel D. White. Textbook on Jurisprudence. London: Blackstone Press Limited, 1996.

Nonet, Philippe and Philip Selznick. Law and Society in Transition, Toward Responsive Law. New York: Harper Colophon Books, 1978.

Nurjaya, I Nyoman. Ed. Politik Hukum Pengusahaan Hutan di Indonesia (Politic of Law on Forestry Management in Indonesia). Jakarta: Wahana Lingkungan Hidup 
Indonesia (WALHI), 1993.

Peluso, Nancy L. Rich Forest, Poor People: Resource Control and Resistance in Java, California: University of California Press, 1992.

Pospisil, Leopold. Anthropology of Law, A Comparative Theory. New York: Harper \& Row Publisher, 1974.

Repetto, Robert and Malcolm Gillis. Public Policies and the Misuse of Forest Resources. New York: Cambridge University Press, 1988.

Starr, June and Jane F. Collier. History and Power in The Study of Law, New Direction in Legal Anthropology. Ithaca and London: Cornel University Press, 1989.

Suhendar, Endang and Ifdal Kasim. Tanah sebagai Komoditi, Kajian Kritis atas Kebijakan Pertanahan Orde Baru [Land as Economic Commodity, A Critical Study of Land Tenure Policy in the New Order Era]. Jakarta: Lembaga Studi dan Advokasi Masyarakat (ELSAM), 1996.

Sumardjono, Maria W. Tanah dalam Perspektif Hak Ekonomi, Sosial, dan Budaya [Land in the Perspective of Economic, Social and Cultural Rights]. Jakarta: Kompas Press, 2008.

Wiradi, Gunawan. Reforma Agraria, Perjalanan Yang Belum Berakhir [The Unfinished Journey of Agrarian Reformation]. Yogyakarta: Insist Press, 2000.

\section{Articles}

Barber, Charles V. "The State, The Environment, and Development: The Genesis and Transformation of Social Forestry Policy in New Order Indonesia." (Unpublished Doctoral Dissertation University of California, Berkeley, 1989).

Glotzbach, Stefanie. "On the Notion of Ecological Justice." (Working Paper Series in Economics University of Luneburg, Germany, 2011).

Moniaga, Sandra. "Toward Community-based Forestry and Recognition of Adat Property Rights in the Outer Islands of Indonesia." (Unpublished Paper, 1991).

Nurjaya, I Nyoman. "Adat Community Land Rights As Defined Within the State Agrarian Law of Indonesia: Is It A Genuine or Pseudo Legal Recognition?" The US-China Law Review Volume 8 Number 4 (April 2011).

Nurjaya, I Nyoman. "State Law in Multicultural Country of Indonesia: Toward A Just and Equitable State in Legal Anthropology Point of View." The US-China Law Review Volume 9 Number 1 (February 2012).

Nurjaya, I Nyoman. "Progressive Environmental Law of Indonesia: Global Principles of Stockholm and Rio Declations As Defined Within The 2009 Act on Human Environment Protection and Management." The US-China Law Review Volume 11 Number 1 (January 2014).

Person, Gerard. "The Tension Between State Law and Local Culture." (Unpublished Paper, 1991).

Schlosber, David. "Three Dimensions of Environmental and Ecological Justice." (Paper presented at Workshop the Nation-state and Ecological Crisis: Sovereinty, European Consortium for Political Research Annual Joint Sessions, 2001).

Tjitradjaja, Iwan. "Differential Access to Resources and Conflict Resolution in A Forest Consession in Irian Jaya." Ekonesia, A Journal of Indonesian Human Ecology Vol. 1 (May 1993).

\section{Website}

Beretta, Ilaria. "Some Highlights on the Concept of Environmental Justice and Its Use." https://eces.revues.org/1135.

Finger, Marina de Oliveira and Felipe Bortoncello Zorzi. "Environmental Justice." UFRGS Model United Nations Journal Vol. 1 (2013): 222-243. 